\title{
Detection of microcystins in the coastal lagoon La Albufera de Valencia, Spain by an enzyme-linked immunosorbent assay (E.L.I.S.A.).
}

\author{
Shane Bradt ${ }^{1}$ and $\mathrm{M}^{\mathrm{a}}$ Jose Villena ${ }^{2}$. \\ 1. Department of Zoology, University of New Hampshire, Durham, NH 03824 - USA \\ 2. Departamento de Microbiología y Ecología, Universidad de Valencia, 46100 Burjassot, España.
}

\begin{abstract}
Over the last twenty years, cyanobacteria have become the predominant phytoplankton in La Albufera de Valencia (coastal lagoon). Dense populations of Planktothrix (Oscillatoria)have been observed, sometimes in excess of $3.10^{5}$ individuals $/ \mathrm{ml}$. This genus has been commonly found to produce microcystins, a hepatotoxin. In order to assess the presence or absence of these toxins in la Albufera, samples were taken in July and August of 1999. Physico-chemical and biological parameters were assessed by standard techniques and microcystin concentrations were measured with an E.L.I.S.A. Concentrations of microcystin were found to range from 5.0 to $2102.9 \mathrm{ng} / 1$ (average $300.1 \mathrm{ng} / \mathrm{l}$ ). Microcystin levels appeared unrelated to the abundance of known microcystin producers (i.e Planktothrix, Microcystis), but were generally higher when Planktolyngbya contorta was abundant and lower during Chroococcus dispersus dominance. This study constitutes the first report of microcystins in Spain.
\end{abstract}

Keywords: microcystin, Albufera de Valencia, phytoplankton, eutrophication, Valencia, Spain, Planktolyngbya contorta

\section{RESUMEN}

Durante los últimos veinte años, las cianoficeas filamentosas han sido el grupo dominante en elfitoplancton de La Albufera de Valencia (laguna costera). Importantes poblaciones de Planktothrix (Oscillatoria) han sido obsewadas en este periodo, llegando en ocasiones a $3.10^{5}$ de individuos por mililitro. Este género ha sido encontrado comunmente como productor de microcistinas, una hepatotoxina. Para evaluar la presencia o ausencia de estas toxinas en La Albufera de Valencia, se tomaron muestras en Julio y en Agosto de 1999.

Los parámetros fisicoquímicos y biologicosfueron analizados con métodos estandary la medicidn de microcistinas se realizo mediante la técnica E.L.I.S.A. Se detectaron concentraciones de microcistinas desde 5.0 hasta $2102.9 \mathrm{ng} / \mathrm{l}$ (300.I ng/l de media). Los niveles de microcistinas no aparecian en relaccidn a la cantidad de productores de microcistinas conocidos (Planktothrix, Microcystis), pero tendian a ser mayores durante el incremento en la población de Planktolyngbya contorta, $y$ menores durante la dominancia de Chroococcus dispersus. Este estudio constituye laprimera cita de microcistinas en España

Palabras clave: microcistinas,Albufera de Valenciafitoplancton, eutrofizacidn, Valencia, España, Planktolyngbya contorta

\section{INTRODUCTION}

La Albufera de Valencia is a shallow, hypertrophic, oligohaline lagoon located $10 \mathrm{~km}$ south of Valencia along the Mediterranean coast of Spain $\left(39^{\circ} 20^{\prime} \mathrm{N}, 0^{\prime \prime} 20^{\prime} \mathrm{W}\right)$. It is located within $\mathrm{La}$ Albufera Natural Park in a densely populated urban area. In the early 1970's, diatoms dominated the system, with increases in blue green algae populations occurring in the summer. Chlorophyll a levels between 1972 and 1974 increased from $13 \mu \mathrm{g} / 1$ in 1972 to $54 \mu \mathrm{g} \cdot \mathrm{l} / \mathrm{lin} 1974$ (Dafauce, 1975), indicating the start of eutrophication. Population growth of surrounding towns and the explosion of industries along the banks of La Albufera (almost a ten-fold increase in factories from the 1970 's to the 1980 's) lead to massive and sustained increases in sewage and industrial 
discharges to the lagoon (Vicente \& Miracle, 1992). These additional inputs lead to a dramatic change in trophic status and phytoplankton composition by the 1980's. In 1981 and 1982, cyanobacteria represented $75-95 \%$ of the phytoplankton community in nearly every month sampled (Garcia et al., 1984; Miracle et al., 1984). Chlorophyll a concentrations at these sampling times $(114-646 \mu \mathrm{g} / \mathrm{l})$ indicated a state of hypereutrophication.

From 1980 to 1988, filamentous blue-green algae accounted for $80-90 \%$ of the total phytoplankton abundance and biomass in La Albufera, (Romo \& Miracle, 1994). Among the dominant cyanobacteria was Planktothrix agardhii. This species was found in $99 \%$ of the samples taken over this period. Mean density was circa 51000 individuals $\cdot m l-1$ (Vicente \& Miracle, 1992), yielding up to $740 \mathrm{mg} / \mathrm{l}$ wet weight (Romo \& Miracle, 1993).

F! agardhii has been found to produce microcystins (Eriksson et al., 1988; Bruno et al., 1992; Luukkainen et al.,1993), a group of hepatotoxins found in several genera of colonial and filamentous cyanobacteria, including Nostoc, Anabaena and Microcystis, (Sivonen et al., 1990a; Namikoshi et al., 1992; Vasconcelos et al., 1995). Even within cyanobacterial species shown to produce microcystins, toxin production is variable. Microcystis aeruginosa isolated from a single lake, for instance, was found to have both toxic and non-toxic strains (Skulberg et al., 1984, 1993). It is estimated that $25 \%$ to $95 \%$ of algal blooms are toxic (Repavich et al., 1990; Sivonen et al., 1990b; Baker \& Humpage, 1994; Pearson, 1994). The effects of microcystins on organisms vary widely; aquatic invertebrates experience decreased feeding rates and reduced reproductive fitness (Hietala et al., 1995; Lauren-Maatta et al., 1997), while vertebrates can be subject to mild illness, tumor promotion and in extreme cases, death (Slatkin et al., 1983; Galey et al., 1987; Falconer \& Humpage, 1996; Jochimsen et al., 1998).

Blooms of hepatotoxic cyanobacteria have become a global concern (Codd et al.,1999b). Toxic blooms have been reported throughout southern Europe, including Portugal (Vasconcelos, 1994; Vasconcelos et al., 1995; Vasconcelos, 1999) and France (Michard et al., 1996; Vezie et al., 1997),. In Spain, blooms of toxic dinoflagellates in marine and freshwater systems (Mariño et al.,1998, Prego et al.,1998), and incidents of potentially-toxic cyanobacterial blooms in freshwater systems (Alvarez et al.,1998) have been reported. However, no reports of the detection of hepatotoxins in Spanish freshwater systems exist to date. The current study represents a first survey of a cyanobacteria-dominated system for presence of microcystins.

\section{MATERIALS AND METHODS}

Samples were taken on three dates (July 14, August 4 and August 26, 1999) at five locations (Fig. 1) in La Albufera (Valencia, Spain, $39^{\circ} 20^{\prime} \mathrm{N}$, $0 " 20^{\prime} \mathrm{W}$ ). Phytoplankton and physico-chemical sampling were performed simultaneously by taking samples at $0.5 \mathrm{~m}$ below the surface with 2 litre PVC containers. Conductivity, dissolved oxygen, temperature and $\mathrm{pH}$ were measured in situ with a WTW MultiLine P4 multiprobe.

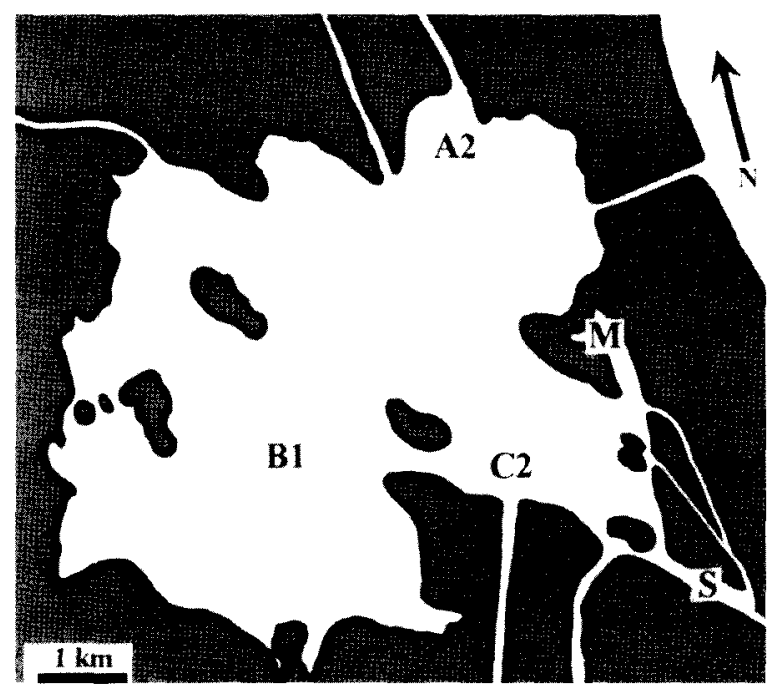

Figure 1. Sampling sites for La Albufera (Valencia, Spain). Site "M" indicates the Mata de Fang and site "S" indicates Sequiota. Puntos de muestreo en La Albufera (Valencia, España). El punto " $M$ " indica La Mata del Fang y el punto "S" indica La Sequiota 
Chlorophyll a concentrations (Shoaf \& Lium, 1976; Burnison, 1980) were determined in the laboratory. Water samples for microcystin analysis were kept cool in the field, then stored at $20^{\circ} \mathrm{C}$. Phytoplankton counts were performed for points $\mathrm{A} 2, \mathrm{~B} 1$ and $\mathrm{C} 2$ (Fig. 1) with an inverted microscope (Olympus IM) according to Utermohl (1958) and reported as individuals per

Table 1. Concentrations of microcystins in $\mathrm{ng} \cdot \mathrm{l}^{-!}$for all sampling points and dates. Values in parentheses are under the detection limit of the assay. Concentración de microcistinas en ng.l- para cada punto de muestreo. Los valores entre paréntesis no llegan al limite de detección.

\begin{tabular}{ccc}
\hline Date & Site & $\begin{array}{c}\text { Microcystin } \\
\text { concentration (ng·l-1) }\end{array}$ \\
\hline \multirow{2}{*}{ July 14, 1999 } & A2 & 76.7 \\
& B1 & $(1.7)$ \\
& c 2 & 132.1 \\
& Mata de Fang & 2102.9 \\
& Sequiota & $(0.7)$ \\
\hline \multirow{2}{*}{ August 3, 1999 } & A2 & 5.0 \\
& B1 & 103.6 \\
& c 2 & 69.3 \\
& Mata de Fang & 52.2 \\
& Sequiota & 934.5 \\
\hline \multirow{2}{*}{ August 26, 1999 } & A2 & 623.0 \\
& B1 & 222.3 \\
& c 2 & $(2.0)$ \\
& Mata de Fang & 160.8 \\
& Sequiota & 14.5 \\
& &
\end{tabular}

milliliter. Phytoplankton classification was based on Germain (1981), Huber-Pestalozzi (1983), Anagnostidis \& Komarek (1988), and Komarek \& Anagnostidis (1999).

Whole lake water (WLW) samples, stored in HDPE sample cups, were subjected to three freeze-thaw cycles to lyse the cells. Samples were thoroughly mixed and $15 \mathrm{~mL}$ transferred into a $30-\mathrm{mL}$ borosilicate-glass serum bottle. The bottles were frozen at a $30^{\prime \prime}$ angle to maximize the exposed surface area of ice. Frozen samples were lyophilized in a Labconco Freezone 4.5 $\left(-50^{\circ} \mathrm{C}, 30^{\prime} 10-3 \mathrm{mbar}\right)$ and then rehydrated with $1.5 \mathrm{~mL}$ of Milli-Q water. This 10 -fold concentration was used to bring the WLW samples into a range that was detectable by the E.L.I.S.A. procedure used. Each sample was filtered through a Whatman PTFE syringe filter $(13 \mathrm{~mm}$ diam, $0.2 \mathrm{~mm}$ pore diameter) into a polypropylene centrifuge tube, which was then frozen until E.L.I.S.A. analyses were performed.

Microcystin analysis was done using an enzyme-linked immunosorbent assay (E.L.I.S.A.). A 96-well microcystin plate kit was used (Envirologix Inc., Portland, ME). Subsamples of the three MC standards provided with the kit (I60, 500, and $1600 \mathrm{ng} / \mathrm{l}$ ) were diluted with Milli$\mathrm{Q}$ water to make up four additional standards at concentrations of $15,25,53$, and $100 \mathrm{ng} / \mathrm{l}$ to extend the sensitivity of the assay. Each of the seven standards was run in duplicate. Due to considerable variation in the $15 \mathrm{ng} / 1$ standard, the

Table 2. Percent composition of phytoplankton from Albufera samples. Porcentaje de los grupos del fitoplancton de La Albufera (Valencia, Spain).

\begin{tabular}{|c|c|c|c|c|c|c|}
\hline Date & Site & Cyanophyceae & Chlorophyceae & Bacillariophyceae & Cryptophyceae & Euglenophyceae \\
\hline \multirow[t]{3}{*}{ July 14, 1999} & $\mathrm{~A} 2$ & 97.7 & 2.3 & $<0.1$ & 0.1 & \\
\hline & B 1 & 97.2 & 2.8 & & & \\
\hline & c 2 & 97.5 & 2.3 & 0.1 & 0.1 & $<0.1$ \\
\hline \multirow[t]{3}{*}{ August 3, 1999} & $\mathrm{~A} 2$ & 96.8 & 3.2 & - & & $<0.1$ \\
\hline & B1 & 97.0 & 2.8 & & 0.1 & $<0 . I$ \\
\hline & c 2 & 98.2 & 1.7 & - & 0.1 & \\
\hline \multirow[t]{3}{*}{ August 26, 1999} & $\mathrm{~A} 2$ & 78.8 & 8.1 & 11.2 & 1.9 & \\
\hline & $\mathrm{B} 1$ & 96.6 & 3.0 & 0.0 & 0.3 & $<0.1$ \\
\hline & c 2 & 96.4 & 3.3 & 0.2 & 0.1 & $<0.1$ \\
\hline
\end{tabular}


$25 \mathrm{ng} / \mathrm{l}$ standard was considered the lowest sensitivity of the assay. Thus, the lowest detectable microcystin concentration is $2.5 \mathrm{ng} / \mathrm{l}$, because of the 10 fold concentration performed on the samples.

Methodology followed the Envirologix protocol provided in each kit. Optical densities (OD) of the wells were read on a Bio-tek (Winooski, VT) EL800 Plate Reader (sensitivity off 0.010 Abs) at a wavelength of $450 \mathrm{~nm}$. KC Junior, a companion program to the plate reader, was used to record the OD from each well and calculate microcystin concentrations based on a cubic loglog standard curve derived from the standards. Wells were also read at a dual wavelength of 630 $\mathrm{nm}$ as a reference to remove any interference that may have been caused from bubbles in the sample or scratches on the plate.

\section{RESULTS}

Microcystin concentrations varied widely, ranging from below detectable limits (b.d.1.) to 2102.9 $\mathrm{ng} / \mathrm{l} \quad($ mean $=300.1 \mathrm{ng} / \mathrm{l})($ Table 1$)$. Variation explained (i.e. $\mathrm{r}^{2}$ ) by E.L.I.S.A. standard curves ranged between $95.6-99.5 \%$. The results of the E.L.I.S.A. were below the detection limit of our methods (i.e. $2.5 \mathrm{ng} / \mathrm{l}$ ) in four. Cyanobacteria

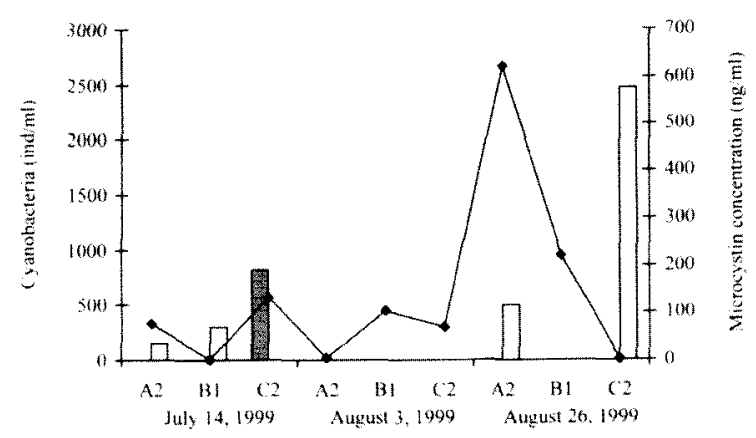

Figure 2. Concentration of microcystin in water samples from La Albufera against densities of known hepatotoxin producers Microcystis aeruginosa (grey columns) and Planktothrix agardhii (white columns). Concentracidn de microcistinas en las muestras de agua de La Albufera frente a concentraciones de conocidos productores de hepatotoxinas Microcystis aeruginosa (columnas grises)y Planktothrix ugaudhii (columnas blancas). were the dominant group in all samples, constituting 78.8-97.7\% of total phytoplankton abundance (Table 2). The concentration of microcystins did not correlate well with the presence of known microcystin producers, such as $M$ aeruginosa and P. agardhii (Fig. 2). However, microcystin levels tended to be lower when $\mathrm{C}$. dispersus was abundant, and higher when $\mathrm{Pl}$. contorta was present in abundance (Fig. 3).

Chlorophyll $a$ concentrations (67-300 $\mu \mathrm{g} \cdot \mathrm{l} / 1$, mean $199 \mu \mathrm{g} / \mathrm{l})$ indicate that La Albufera is currently less eutrophic than during the 1980's. In spite of this, cyanobacteria dominated the phytoplankton at all sampling locations on all three sampling dates (Table 2). C. dispersus and $P$ contorta were the most common cyanobacteria and together accounted for $74 \%-87 \%$ of cyanobacteria total abundance. M. aeruginosa and P. agardhii were occasionally found, but never accounted for more than $0.1 \%$ of total cyanobacteria.

No significant relationships were found between microcystin concentrations and any of the biological and chemical characteristics measured. Also, microcystin concentrations did not correlate with the presence of known microcystin-producing species (Fig. 2), indicating that the $M$. aeruginosa and $P$. agardhii found in the water column were not directly responsible for the microcystins detected. However, a shift in dominance between C. dispersus and I? contorta correlated with changing microcystin levels (Fig. 3). Microcystin concentrations increased with increasing I? contorta concentrations, while the opposite trend was observed with C. dispersus.

\section{DISCUSSION}

Microcystins were detected in La Albufera at relatively low levels (i.e. b.d.l to $2102.9 \mathrm{ng} / \mathrm{l}$ ). In a study of 17 Wisconsin lakes, McDermott et al., (1995) used an E.L.I.S.A. to test for microcystins. The reported concentrations (maximum $=56000 \mathrm{ng}-1$, average $=16085 \mathrm{ng} / \mathrm{l})$ were much higher than those found in La Albufera. Ueno et al. (1996) tested lakes and reservoirs across Japan, Thailand, Germany and Portugal 
(a)

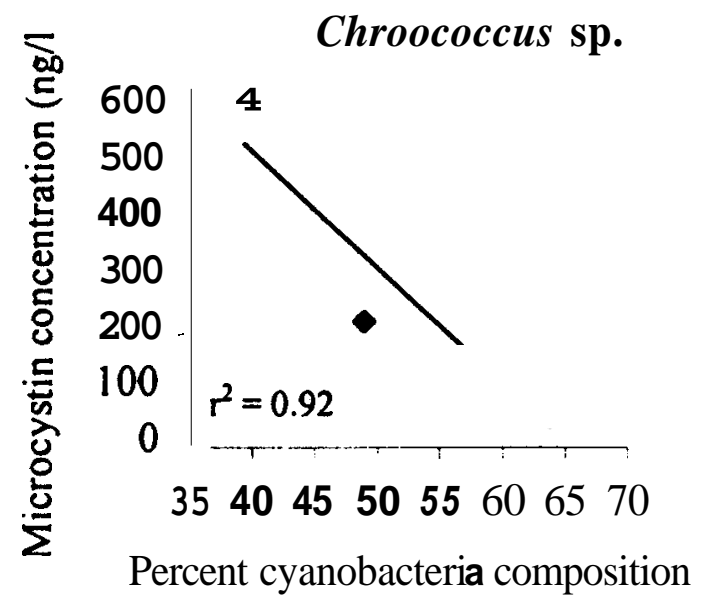

(c)

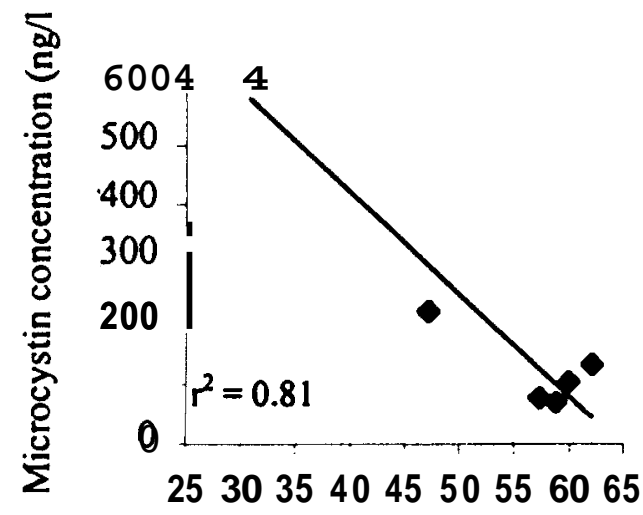

Percent phytoplankton composition (b)

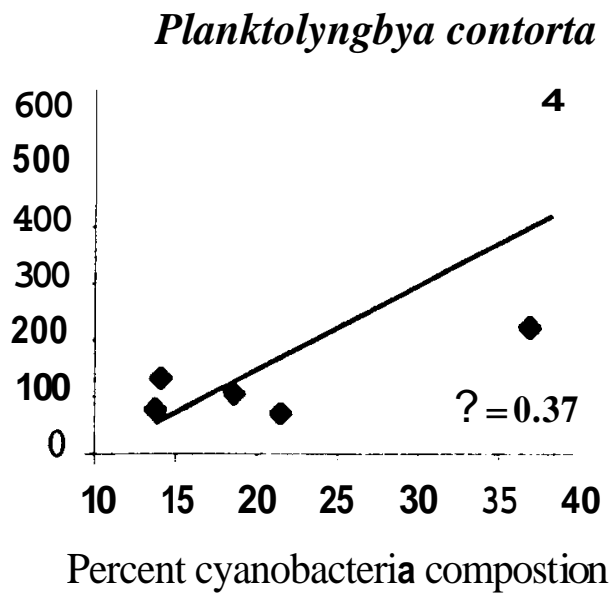

(d)

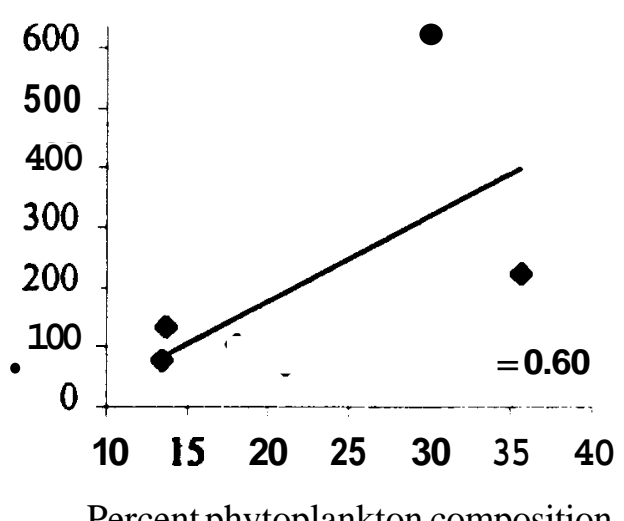

Percent phytoplankton composition

Figure 3. Relationships between microcystin concentration in Albufera and percent composition of Chroococcus dispersus and Planktolyngbya contortu. Graphs (a) and (b) are based on percent compostion in relation to all phytoplankton, while (c) and (d) are based on composition of cyanobacteria only. Correlucion entre las concentraciones de microcistinas del agua de la Albufera y el porcentuje de Chroococcus dispersus y Planktolygbya contorta. Las gráficas (a)y (b) estan basudas en elporcentuje de fitoplancton total, mientras (c) y (d) estan basadas en elporcentaje de ciunobucterius.

with an E.L.I.S.A. assay from 1993-1995. Maxim varied widely (i.e. Japan: $1.300 .000 \mathrm{ng} / \mathrm{l}$, Thailand: 200 ng/l, Germany: 36000 ng/l, Portugal: $37000 \mathrm{ng} / \mathrm{l}$ ), but in general were at least an order of magnitude greater than the highest level detected in the current study.

However, the maximum microcystin concentration in La Albufera (2102.9 ng/l) was higher than that in the majority of the microcystin-containing lakes surveyed in both studies (Wisconsin - 63\%, Japan - 53\%, Germany - 64\%, Portugal - 54\%).

It appears that $P$. contorta was responsible for most microcystin production in La Albufera, although no direct evidence was found as phytoplankton samples were not isolated and tested. Production by this species would fit reports of 
toxin production by Oscillatoriales (Eriksson et al., 1988; Bruno et al., 1992, Luukkainen et al., 1993, Brittain et al., 2000). Although the correlation between $\%$ total abundance of I? contorta and microcystin concentrations was relatively high $\left(\mathrm{r}^{2}\right.$ $=0.60$ ) (Fig. 3), a great deal of the variation in microcystin levels is still unaccounted for. C. dispersus as a percentage of total phytoplankton exhibited a strong correlation with microcystin concentrations $\left(r^{2}=0.81\right)$. When regressions were based on percent of this species over total cyanobacteria, the effect of $P$. contorta decreased $\left(\mathrm{r}^{2}=0.37\right)$, while that of $\mathrm{C}$. dispersus increased $\left(\mathrm{r}^{2}=0.92\right)$. It may be that $\mathrm{C}$. dispersus displaces microcystin-producing cyanobacteria, thus acting to limit microcystin concentrations when dominant. It could also be possible that the conditions which favour the growth of $C$. dispersus do not favour the production of microcystins.

There are several possible explanations for the unexplained variation in microcystin production seen in La Albufera. One could be the lack of comprehensive knowledge of all genera and species of cyanobacteria capable of microcystin production. The focus of many microcystin studies has been large, colonial, bloom-forming genera and species. Studies continually add to the list of microcystin producers, and have begun to include smaller, less studied species (Domingos et al., 1999). In addition, even known microcystin producers, such as $M$. aeruginosa, can be present in both toxic and non-toxic strains within the same lake (Skulberg et al., 1984, 1993).

The amount of variation may also be attributed to the physical characteristics of La Albufera. Many forms of cyanobacteria have a tendency to float to the surface of lakes under certain conditions, while under others, cyanobacterial cells may accumulate in the benthos, through sedimentation or as a benthic phase of their life cycle (Barbiero \& Welch, 1992; Threlkeld, 1994). Not only could cyanobacteria be found throughout the water column and/or in the sediments of $\mathrm{La}$ Albufera, they may also be frequently displaced from what would constitute a "normal" location. Since the lagoon is large (i.e. $21 \mathrm{~km} 2,7 \mathrm{~km}$ across) and quite shallow (i.e. average depth
$0.75 \mathrm{~m}$ ), wind and lack of thermal stratification provide a great deal of mixing. The concentration and location of microcystins are related to the length of time the toxin is present in $\mathrm{La}$ Albufera after its production. While some reports attest to the good stability of microcystins through their resistance to various types of chemical and physical degradation (Watanabe et al., 1992; Tsuji et al., 1994), other studies have exhibited microbial degradation of microcystins (Jones et al., 1994, Rapala et al., 1994, Inamori et al., 1998). Most of these studies found that toxins are still detectable after 15-30 days of degradation. Microcystins have been found to interact with other substances in the water and bind to particulate matter (Rapala et al., 1994, Lahti et al., 1997). Therefore, even if cyanobacterial cells did not precipitate, free microcystin could be bound to other particles and settle out of the water column. In all cases, i.e. free microcystins in the water, inside of floating cells, inside precipitating cells, adsorbed to particulate matter, it is possible they are being constantly redistributed throughout the water column and benthic zone in a wellmixed system such as la Albufera.

Since La Albufera was historically more eutrophic and contained greater populations of known microcystin producers, such as I? agardhii (Vicente \& Miracle, 1992; Romo \& Miracle, 1993), it is possible that microcystin concentrations were greater in the 1980's than today. However, Jones et al. (1994) suggested that biodegradation of microcystins may commence more quickly in bodies of water which experience frequent exposure to microcystin-producing cyanobacteria. Therefore, it is possible that $\mathrm{La}$ Albufera may contain a large community of organisms ready to degrade the toxin. This could help explain the relatively low concentration of microcystins relative to the extremely high concentrations of cyanobacteria and chlorophyll $a$. In all samples, except for the July 14 sample of the Mata de Fang, microcystin concentrations were below standards proposed by the World Health Organization (1998) for microcystin-LR in drinking water (i.e. $1 \mu \mathrm{g} / \mathrm{l}$ ), and more recent standards by Falconer et al. (1999) suggested for 
"relatively mild and/or low probabilities of adverse health effects" (2-4 $\mu \mathrm{g} / \mathrm{l})$.

Even though current levels in La Albufera likely pose little acute risk to humans, there is a moderate potential for chronic effects. Although not used as a drinking water source, thus minimizing human exposure, even low level exposure to microcystins has been found to promote liver cancer (Ueno et al., 1996). It is more probable that wildlife (fish, birds, amphibians) could be affected, because of their direct contact with the lake water, and resultant higher concentrations due to bioaccumulation. In addition, microcystins have been found to accumulate in lettuce when microcystin-containing water was used for their cultivation (Codd et al., 1999a). A slight possibility may exist for accumulation of microcystins in plants in rice fields surrounding La Albufera. However, the potential accumulation in rice grains appears to be smaller than that in lettuce leaves.

La Albufera provides an opportunity for the study of microcystins in an oligohaline environment. Few studies on cyanobacterial toxicity have been conducted in brackish environments. Although La Albufera is oligohaline, thus only slightly saline relative to sea water, it provides a system which is more saline than the vast majority of lake systems, but fresh enough to allow for cyanobacterial dominance (Paerl 1988 1996; Codd, 1998). Comprehensive studies are needed on the seasonal dynamics of microcystins in La Albufera to better assess conditions of this unique system as well as potential impacts to animal and human populations.

\section{ACKNOWLEDGEMENTS}

The authors would like to thank Eduardo Vicente, and Antonio Camacho for help with arrangements for S.R.B. in Valencia, Rosa Miracle, Susana Romo and the Shallow Wetland Lake Function and Restoration in a Changing European Environment (S.W.A.L.E.) Project (ENV4-CT97-0420) for providing access to phytoplankton data, Maria Sahuquillo for help with sample collection, the Conselleria de Medio Ambiente de Valencia for providing physicochemical data, Dr. James Haney and Rich Hathaway for their assistance with the E.L.I.S.A. analyses, and Amy Sevcik and Luis Santamaria for logistical assistance. The research was supported by the use of facilities and materials at the University of Valencia and University of New Hampshire (U.N.H.) and funded by two research grants to S.R.B., from the Center of Marine Biology and the Graduate School, both at U.N.H., and a grant to M.J.V. from the S.W.A.L.E. Project. Final thanks to the Fulbright Commission, for a grant to S.R.B. in 1996-97 which made this collaboration possible.

\section{LITERATURE CITED}

ANAGNOSTIDIS, K. \& J. KOMÁREK. 1988. Modern approach to the classification system of cyanophytes. 3 - Oscillatoriales. Arch. Hydrobiol (Suppl S0) Algological Studies: 327-472.

ALVAREZ, M. J., A. BASANTA, V. LOPÉZ-RODAS \& E. COSTAS. 1998. Indentification of different serotypes during a Microcystis aeruginosa bloom in a SW Spanish reservior. VII International Conference on Harmful AlgaeVigo, Spain: 291-294.

BAKER, P. D. \& A. R. HUMPAGE. 1994. Toxicity associated with commonly occurring cyanobacteria in surface waters of the Murray-Darling Basin, Australia.Aus. J. Mar. Fresh. Res., 45: 773-786.

BARBIEKO, R. P. \& E. B. WELCH. 1992. Contribution of benthic blue-green algal recruitment to lake populations and phsophorus translocation. Freshwater. Biol., 27: 249-260.

BRITTAIN, S.,Z. A. MOHAMED, J. WANG, V. K. B. LEHMANN, W. W. CARMICHAEL \& K. L. RINEHART. 2000. Isolation and characterization for microcystins from a River Nile strain of Oscillatoria tenuis Agardh ex Gomont. Toxicon, 38: 1759-1771.

BKUNO, M., P. GUCCI, E. PIERDOMINICI, P. SESTILI, A. IOPPOLO, N. SECHI \& L. VOLTEKKA. 1992. Microcystin-like toxins in different freshwater species of Oscillatoria Toxicon, 30: 1307-13I1.

BURNISON, B.K. 1980. Modified dimethyl sulfoxide extraction for chlorophyll analysis of phytoplankton. Can. J. Fish. Aguat. Sci.,37: 729-733. 
CODD, G. A. 1998. Cyanobacterial blooms and toxins in fresh-, brackish and marine waters. VII International Conference on Harmful Algae. Vigo, Spain:13-17.

CODD, G. A., J. S. METCALF \& K. A. BEATTIE. 1999a. Retention of Microcystis aeruginosa and microcystin by salad lettuce (Lactuca sativa) after spray irrigation with water containing cyanobacteria. Toxicon. 37: 1181-1185.

CODD, G A., C. J. WARD, K. A. BEATTIE \& S. G. BELL. 1999b. Widening perceptions of the occurrence and significance of cyanobacterial toxins. In: The Phototrophic Prokaryotes, G. A. Peschek, W. Loffelhardt and G. Schemetter (eds.): 623-632 Kluwer Academic / Plenum Publishers, New York, USA.

DAFAUCE, C. 1975. La Albufera de Valencia. Un estudio pioloto. Monografias ICONA: 4 Madrid. $127 \mathrm{pp}$.

DOMINGOS, P., T. K. RUBIM, R. J. R. MOLICA, S. M. F. O. AZEVADO \& W. W. CARMICHAEL. 1999. First report of microcystin production by picoplanktonic cyanobacteria isolated from a northeast brazilian drinking water supply. Environ. Toxicol., 14: 31-35.

ERIKSSON, J., J. MERILUOTO, H. KUJARI \& O. SKULBERG. 1988. A comparison of toxins isolated from the cyanobacteria Oscillatoria agardhii and Microcystis aeruginosa Comp Biochem. Phys. B, 89C: $207-210$.

FALCONER, I. R. \& A. R. HUMPAGE. 1996. Tumour promotion by cyanobacterial toxins. Phycologia, 35 (6 Suppl.): 74-79.

FALCONER, I, J. BARTRAM, I. CHORUS, T. KUIPER-GOODMAN, H. UTKILEN, M. BURCH \& G. A. CODD. 1999. Safe levels and safe practices. In: Toxic cyanobacteria in water. I. Chorus and J. Bartman (eds.): 155-178. E \& FN Spon, London, England.

GALEY, F. D., V. R. BEASLEY, W. W. CARMICHAEL, G. KLEPPE, S. B. HOOSER \& W. M. HASCHEK. 1987. Blue-green algae (Microcystis aeruginosa) hepatotoxicosis in dairy cows. Am J. Vet.Res., 48: 1415-1420.

GARCÍA, M. P., E. VICENTE \& M. R. MIRACLE. 1984. Sucesion estacional del fitoplancton de la Albufera de Valencia. Anales de Biología, (Sec. Esp. 2): 91-100.

GERMAIN, H. 1981. Flore des Diatomées 444 pp.

HIETALA, J., M. REINIKAINEN \& M. WALLS. 1995. Variation in life-history responses of
Daphnia to toxic Microcystis aeruginosa. J. Plankton. Res., 17: 2307-2318.

HUBER-PESTALOZZI, G. 1983. Das Phytoplankton des Sübwassers Systematik und Biologie 7(1) Chlorophyceae. E. Schweizerbart'sche Verlagsbuchhandlung. 1044 pp.

INAMORI, Y., N. SUGIURA, N. IWAMI, M. MATSUMURA, M. HIROKI \& M. M. WATANABE. Degradation of the toxic cyanobacterium Microcystis viridis using predaceous micro-animals combined with bacteria. Phyco. Res , 46 (Suppl.): 37-44.

JOCHIMSEN, E. M., W. W. CARMICHAEL, J. AN, D. M. CARDO, S. T. COOKSON, E. M. HOLMES, M. B. D. C. ANTUNES, D. A. D. M. FILHO, T. M. LYRA, V. S. T. BARRETO, S. M. F. O. AZEVEDO \& W. R. JARVIS. 1998. Liver failure and death after exposure to microcystins at a hernodialysis center in Brazil. New England $J$. Med., 338: 873-878.

JONES, G. J., D. G. B OURNE, R. L. BLAKELEY \& H. DOELLE. 1994. Degradation of the cyanobacterial hepatotoxin microcystin by aquatic bacteria. Nat Toxins, 2: 228-235.

KOMAREK, J. \& K. ANAGNOSTIDIS. 1999. Sübwassers von Mitteleuropa 19(I) Cyanoprokaryota Gustav Fischer. 548 pp.

LAHTI, K., J. RAPALA, M. FÄRDIG, M. NIEMELA \& K. SIVONEN. 1997. Persistence of cyanobacterial hepatotoxin, microcystin-LR in particulate material and dissolved in lake water. Wat. Res , 31 : 1005-1012.

LAUREN-MAATTA, C., J. HIETALA \& M. WALLS. 1997. Responses of Daphnia pulex populations to toxic cyanobacteria. Freshwater. Biol, 37: 635647.

LUUKKAINEN, R., K. SIVONEN, M. NAMIKOSHI, M. FARDIG, K. L. RINEHART \& S. I. NIEMELA. 1993. Isolation and identification of eight microcystins from thirteen Oscillatoria agardhii strains and structures of a new microcystin. Appl Environ. Micro., 59: 2204-2209.

MARIÑO, J., J. MANEIRO \& J. BLANCO. 1998. The harmful algae monitoring programme of Galicia: good value for money. VII International Conference on Harmful Algae Vigo, Spain:229-232.

MCDERMOTT, C.M., R. FEOLA, \& J. PLUDE. 1995. Detection of cyanobacterial toxins (microcystins) in waters of northeastern Wisconsin by a new immunoassay technique. Toxicon, 33: 14331442. 
MICHARD, M., L. ALEYA \& J. VEFWEAUX. 1996. Mass occurrence of the Cyanobacteria Microcystis aeruginosa in the hypereutrophic Villerest Reservior (Roanne, France): Usefulness of the biyearly examination of the NIP (nitrogen phosphorus) and $\mathrm{P} / \mathrm{C}$ (protein/carbohydrate) copulings. Arch. Hydrobiol ., 135: 337-359.

MIRACLE, M. R., M. P. GARCÍA \& E. VICENTE. 1984. Heterogenidad de las comundades fitoplanctonicas de la Albufera de Valencia. Limnetica, 1: 20-31.

NAMIKOSHI, M., K. SIVONEN, W. R. EVANS, W. W. CARMICHAEL, L. ROUHIAINEN, R. LUUKKAINEN \& K. L. RINEHART. 1992. Structures of three new homotyrosine-containing microcystins and a new homophenylalanine variant from Anabaena sp. strain 66. Chem. Res. Toxicol., 5: 661-666.

PAERL, H. W. 1988. Nuisance phytoplankton blooms in coastal, estuarine and inland water. Limnol. Oceanogr., 33: 823-847.

PAERL, H. W. 1996. A comparison of cyanobacterial bloom dynamics in freshwater, estuarine and marine environments. Phycologia, 35: 25-35.

PEARSON, M. J. 1994. The occurrence of toxic cyanobacteria in the UK Toxic cyanobacteria: current status of research and management. Adelaide, Australia: 19-22.

PREGO, R., Y. PAZOS, J. MANEIRO \& J. MARIÑO. 1998. First bloom of silicoflagellate Dictyocha speculum causing salmon mortality in a Galician RIa (NW Spain). VII International Conference on Harmful Algae Vigo, Spain: 106.

RAPALA, J., K. LAHTI, K. SIVONEN \& S. 1. NIEMELA. 1994. Biodegradability and adsorption on lake sediments of cyanobacterial hepatotoxins and anatoxin-a. Let. Appl. Micro., 19:423-428.

REPAVICH, W. M., W. C. SONZOGNI, J. H. STANDRIDGE, R. E. WEDEPOHL \& L. F. MEISNER. 1990. Cyanobacteria (blue-green algae) in Wisconsin waters: acute and chronic toxicity. Water Res., 24: 225-231.

ROMO, S. \& M. R. MIRACLE. 1993. Long-term periodicity of Planktothrix agardhii, Pseudoanabaena galeate and Geitlerinema sp. in a shallow hypertrophic lagoon, the Albufera of Valencia (Spain). Arch. Hydrobiol., 126: 469-486.

ROMO, S. \& M. R. MIRACLE. 1994. Long-term phytoplankton changes in a shallow hyper trophic lake, Albufera of Valencia (Spain). Hydrobiologia, 2751276: 153-164.
SHOAF, W. T. \& B. W. LIUM. 1976. Improved extraction of chlorophylla and $\mathrm{b}$ from algae using deimethyl sulfoxide. Limnol. Oceanogr., 21:926-928.

SIVONEN, K., W. W. CARMICHAEL, M. NAMIKOSHI, K. L. RINEHART, A. M. DAHLEM, \& S. I. NIEMELA. 1990a. Isolation and characterization of hepatotoxic microcystin homologs from the filamentous freshwater cyanobacterium Nostoc sp strain 152.Appl. Environ. Microb., 56: 2650-2657.

SIVONEN, K., S. I. NIEMELA, R. M. NIEMI, L. LEPISTO, T. H. LUOMA \& L. A. RASANEN. 1990b. Toxic cyanobacteria (blue-green algae) in Finnish fresh and coastal waters. Hydrobiologia, 190: 267-275.

SKULBERG, O. M., G. A. CODD \& W. W. CARMICHAEL. 1984. Toxic blue-green algal blooms in Europe: A growing problem. Ambio, 13:244-247.

SKULBERG, O. M., W. W. CARMICHAEL, G. A. CODD \& R. SKULBERG. 1993. Taxonomy of toxic Cyanophyceae (Cyanobacteria). In: Algal Toxins in Seafood and Drinking Water I. R. Falconer (eds.): 145-164. Academic Press, London, England.

SLATKIN, D. N., R. D. STONER, W. H. ADAMS, J. H. KYCIA \& H. W. SIEGELMAN. 1983. Atypical pulmonary thrombosis caused by toxic cyanobacterial peptide. Science, 220: 1383-1385.

THRELKELD, S. T. 1994. Benthic-pelagic interactions in shallow water columns: an experimentalist's perspective. Hydrobiologia, 2751276: 293-300.

TSUJI, K, S. NALTO, F. KONDO, N. ISHIKAWA, M. F. WATANABE, M. SUZUKI \& K.-I. HARADA. 1994. Stability of microcystins from cyanobacteria: effect of light on decomposition and isomerization. Environ. Sci. Technol., 28: 173-177.

UENO, Y., S. NAGATA, T. TSUTSUMI, A. HASEGAWA, F. YOSHIDA, M. SUTTAJIT, D. MEBS, M. PUTSCH \& V. VASCONCELOS. 1996. Survey of microcystins in environmental water by a highly sensitive immunoassay based on monoclonal antibody. Nat. Toxins, 4: 271-276.

UTERMOHL, H. 1958. Zur Vervollkommnugn der quantitativen Phytoplankton-Methodi k. Mitt. Int. Ver. Limnol., 9: 1-38.

VASCONCELOS, V. M. 1994. Toxic cyanobacteria (blue-green algae) in Portuguese fresh waters. Arch. Hydrobiol., 130: 439-451.

VASCONCELOS, V. M. 1999. Cyanobacterial toxins in Portugal: effects on aquatic animals and risk for human health. Braz. J. Med. Biol. Res., 32: $249-254$. 
VASCONCELOS, V. M., K. SIVONEN, W. R. EVANS, W.W. CARMICHAEL \& M. NAMIKOSHI. 1995. Isolation and characterization of microcystins (heptapeptide hepatotoxins) from Portuguese strains of Microcystis aeruginosa Kutz. emend Elekin. Arch. Hydrobiol ., 134:295305.

VEZIE, C., L. BRIENT, K. SIVONEN, G. BERTRU, J. C. LEFEUVRE \& M. SALKINOJA-SALONEN. 1997. Occurrence of microcystin-containing cyanobacterial blooms in freshwaters of Brittany (France). Arch. Hydrobiol ., 139: 401-413.
VICENTE, E. \& M.R. MIRACLE. 1992. The coastal lagoon Albufera de Valencia: An ecosystem under stress. Limnetica, 8: 87-100.

WATANABE, M. F. , K. TSUJI, Y. WATANABE, K. I. HARADA \& M. SUZUKI. 1992. Release of heptapeptide toxin (microcystin) during the decomposition process of Microcystis aeruginosa. Nat. Toxins, I: 48-53.

WORLD HEALTH ORGANIZATION. 1998. Guidelines for drinking-water quality (Second edition): Health criteria and other supporting information. $36 \mathrm{pp}$. 